\title{
Eating disorders and self-harm in Japanese culture and cultural expressions
}

\author{
GITTE MARIANNE HANSEN
}

\begin{abstract}
Since the 1980s, eating disorders and self-harm among Japanese women have been on the rise. This socio-cultural study suggests that these behaviours are based in Japanese culture and have today become a female lifestyle. Motivated by cultural and historical constructions of femininity and the fear of social disintegration, this female lifestyle expresses a paradox: an attempt by women to over-perform and at the same time escape the obligation to navigate normative femininity. In parallel, eating disorders and self-harm are explicitly thematized in Japanese cultural expressions, from literature and manga to films and popular music. Using accounts from women engaged in this lifestyle, in addition to various fictional representations, this study conceptualizes a set of socio-psychological markers that exposes how eating disorders and self-harm are potentially represented in cultural expressions where such behaviours are not explicitly thematized. Miyazaki Hayao's animation Sen to Chihiro no kamikakushi from 2001 serves as an example of how eating disorders, as a female lifestyle, have become a normative form of entertainment.
\end{abstract}

Keywords: eating disorders; self-harm; contradictive femininity; Japanese cultural expressions; fiction; representation; Miyazaki Hayao.

\section{日本文化における摂食障害と自傷行為}

$$
\text { ギッテ・マリアンネ・ハンセン }
$$

1980 年代以降、日本では女性の摂食障害と自傷行為が増加の傾向を見 せるようになった。社会文化的なアプローチをとる本稿では、これら の行為が、日本文化に根ざし、いまや女性の日常的な生き方に組み込 まれていることを示したい。 
文化的 ·歴史的に構築されたフェミニニティと社会的疎外への怖れを 要因として、日本女性の生き方は、一方で過度にフェミニニティに加 担しながら、他方では規範的な「女らしさ」に組み入れられることか ら逃れようとするという逆説的なあり方を示している。

これと平行して、摂食障害と自傷行為は日本の文学、マンガ、映画か ら歌謡曲に至るまでの日本の文化的表現領域で、明白な形で主題化さ れている。

これらさまざまな媒体における表象に、こうした生き方のうちにある 女性の経験に立つ記録等を加え、本稿は、摂食障害と自傷行為の問題 がいまだ明白な形で意識されていない社会で、こうした社会心理学的 な表象と指標がいかにこれらの問題を顕在化させるうえで力を発揮す るかを、概念化するものである。宮崎駿の2001年公開のアニメ映画 「千と千尋の神隠し」は、女性の生き方の問題としての摂食障害がいか に一般的娛楽のレベルで規範化の対象になるものであるかを考えるうえ で、一助となるはずである。

\section{Introduction}

Miyazaki Hayao's Sen to Chihiro no kamikakushi (2001) has been globally praised for its artistic merits and positive portrayal of female gender roles (Coeyman 2002). Kamikakushi literally means "to be spirited away" and refers to the Japanese folk tale according to which women and children, especially shōjo [little girls], become hidden in, or spirited away into, another world (Iijima 1987: 47; Yanagita 1976 [1910]: 19; Yanagita 1976 [1926]: 114-119). Accordingly, the main plot concerns the spiriting away of the shojo "hero" protagonist, Chihiro, into a fantastic kamikak$u s h i$ world where she toils hard in a strange bathhouse and rescues her parents, who have been transformed into pigs. However, upon closer examination, Chihiro's fantastic adventure is not as remote from reality as we might think. Her battle takes place in a world where humans risk transforming into pigs if they eat - making food and eating dangerous elements - and her shojo heroism relies on two main competencies: refusing to consume (she declines to eat with her parents) and expelling the consumed (she defangs monsters by making them throw up).

While it seems unlikely that Miyazaki intended to express issues such as anorexia and bulimia, his animation was produced in and consumed by individuals in a cultural setting where restricting food-intake and throwing up are realities many women face in their daily lives. As such, the film participates in the discourse of eating disorders, albeit via an embedded storyline, ${ }^{1}$ just like cultural expressions explicitly thematizing such issues have done over the past three decades, including Matsumoto Yūko's novel Kyoshokushō no akenai yoake (1987), Anno 
Moyoko's manga Shibō to iu na no fuku o kite (1997) and Kanehara Hitomi's novel Haidora (2007). Commenting on her novels, Kanehara has often referred to her own experiences with self-harm (Hosogai 2003), but although works that explicitly thematize eating disorders and self-harm are often created from the producer's personal experience, it is important to consider that this may not always be the case.

Clinical definitions of eating disorders and self-harm are relatively rigid (Asano 1998 [1996]: 19-20) and often exclude individuals who fall slightly outside the criteria (for clinical definitions, see Kiriike 2001: $63-71,153-159)$. A review of clinical surveys on eating disorders and self-harm statistics in Japan (e.g., Makino et al. 2006; Nakamura et al. 1999; Yamaguchi and Matsumoto 2005) reveals that most of these rely exclusively on self-reports using multiple-choice questionnaires and do not account for the level of candour among survey participants. Since individuals with eating disorders and self-harm often try to conceal their behaviour, it is therefore difficult to accurately gauge the extent of these problems. Despite this, the general trend from studies and interviews indicates that eating disorders and self-harm are today a complex and diverse problem among Japanese women of all ages. ${ }^{2}$ In fact, women in many parts of the world are affected by these issues, but since motivational factors vary culturally (Lee 2001: 47), this study limits itself to Japan.

Inspired by the idea that mental illness is not an objective fact, but an historically specific social construct (Foucault 1972: 32), and by feminist socio-scientific analysis of eating disorders and self-harm (Bordo 1993; Katō 2004; McGilley 2004; Pike and Borovoy 2004), I understand eating disorders and self-harm behaviour as a contemporary strategy for women to perform femininity, ${ }^{3}$ or restated less theoretically, a contemporary female lifestyle. Based on diverse socio-cultural approaches to representation (see Hall 1997), this paper aims to show the interconnectedness between real life and fictional representations of eating disorders and self-harm, identify the motivational factors for these lifestyles and conceptualize a set of socio-psychological markers that can expose eating disorders and self-harm as embedded storylines in Japanese cultural expressions. The works discussed throughout do not represent a mutually exclusive, comprehensively exhaustive list of cultural expressions thematizing eating disorders and self-harm, but rather are examples that through their diversity in genre illustrate how eating disorders and selfharm are deeply rooted in contemporary Japanese culture.

\section{Femininity and the cultural setting}

In basic terms, eating disorders and self-harm refer to individuals who violate their own body through insufficient or excessive food intake, or 
who intentionally harm their own body by mutilating it. These practices require an extreme tolerance of pain and hunger, self-control and selfsubmission - a combination that highlights the complexity of these behaviours. Mapping out a brief picture of select historical constructions of femininity and its relationship with women's eating, pain and self-control, may assist our understanding of what motivates women to engage in self-destructive behaviour. Here, I only present brief glimpses of a limited selection of historical documents and it is not my intention to draw any conclusion about historical understandings of femininity in general. However, demonstrating how some historical constructions of dangerous and good women share elements with contemporary femininity, and indeed with eating disorders and self-harm, helps reveal a possible socio-historical connection between women and these behaviours.

The first example I wish to draw attention to is "Meshi kuwanu onna", a yamanba [mountain-crone] folk tale, which has already been associated with eating disorders by Jungian psychologists (Kawai 1982; Yamaguchi 2009: 55-94). Several variations of this tale exist; the one presented here is from Kawai Hayao's Mukashibanashi to nihonjin no kokoro (1982: 338-340). In this tale, the yamanba appears as a perfect woman - beautiful, obedient, nurturing and most importantly, does not eat - or so it seems. Desiring a woman who does not eat, the male protagonist is immediately attracted to her and they marry. Spying on her, the husband is horrified to discover her swallowing large quantities of rice balls and mackerel through an enormous mouth that is exposed on her scalp as she loosens her hair. When he confronts her, she devours his friend and tries to eat him too, but he narrowly escapes her ravenous appetite. This tale relies on a storyline that connects the indulging female to something unfeminine, unnatural and horrible, implying that a good female is comely, obedient, nurturing and in control of her appetite - to a normal extent. The man's act of spying, when she thinks she is alone, finally reveals her true nature (Kawai 1982: 43).

The second example is Kaibara Ekiken's Edo-period philosophical text Onna daigaku (1911 [1762]), in which the good female is constructed as opposite to the dangerous yamanba. By calling upon parents to raise their daughters appropriately, Kaibara emphasizes the passive nature of women, whose only beneficial qualities are gentle obedience, chastity, mercy and quietness - competencies that are upheld through self-inspection and self-reproach. A woman must be free of selfishness, not overindulge in food, tea or alcohol, sleep little and obey her husband and his parents. Problems in the family are inevitably due to her evil nature and lack of proper female behaviour (Kaibara 1911 [1762]: 686-691). Read today, Kaibara's understanding of femi- 
ninity seems contradictory - women were expected to make an effort and punish themselves into becoming what was in fact thought to be their true nature.

The yamanba tales and Kaibara's writings may have been relegated to library shelves, but the constant retelling of women as uncontrollable, shameful and defiled has cultivated a sense of truth that is today an inseparable part of the Japanese socio-cultural fabric, or, drawing on Roland Barthes' thoughts, history has indeed been transformed into nature (1975 [1972]: 129). In today's Japan, a good woman is still expected to think of others before herself and women who do not conform to this norm are socially disintegrated, portrayed as ill-willed and treacherous. The girl fashion of the late 1990s typified by excessive makeup and wild hair is interestingly termed yamanba-musume [yamanba-daughters], and these girls have been specifically criticized for not conforming to societal expectations of ordinary teenage girls (Kinsella 2005: 144, 147).

Another present day incarnation of the yamanba tale and Kaibara's female code is the value of a controlled appetite. In contemporary Japan, the diet industry is an extremely profitable business (Miller 2006: 159-175), and the competence of women to exhibit a well-behaved appetite is valued more than ever. Dieting has become a form of female entertainment not only in advertising and magazines but also in computer games, where points are scored for successfully losing weight (Miller 2006: 168, 172). The discourse that women should possess a controlled appetite is also being sold at any department store in the form of the traditional two piece set of teacups, rice bowls and chopsticks aimed at married couples, which always contain two different sizes - one big for the man and one small for the woman. However, exhibiting a controlled appetite must be balanced with a display of cute female desire for cake and desserts, and some restaurant menus state explicitly that certain sweets are intended for women. Despite such contradictions, women are indeed becoming smaller. The average Body Mass Index (BMI) among women has decreased from 21.0 in 1980 to 20.5 in 1995, against an increase for the average of the entire population (Kiriike 2001: 17; Miller 2006: 160-161), and Japanese doctors today worry what consequences women's low BMI will have on their babies in the future. ${ }^{4}$

Although displaying a controlled appetite is part of the female ideal, the all-consuming nature threatens at any moment. For example, in a 2008 television spot for the Kasugai-brand black sugar candy, a normal looking (thin) woman snatches a cake from a male co-worker using a non-human arm that protrudes from a suddenly exposed opening on her scalp. The gimmick is that this happens so quickly that nobody, 
including the woman herself, notices what happened to the cake. Only the viewer sees what really happened when the entire event is repeated in slow-motion. Considering "Meshi kuwanu onna", this advertisement plays with the idea that normal women have a hidden, unfeminine, allconsuming yamanba in them, which they can avoid exposing by keeping their cravings under control with Kasugai candy. A search of futaguchi onna [two-mouthed woman] in Google Images furthermore shows that the all-consuming female with an additional grotesque mouth on her scalp is omnipresent in Japanese culture, rendered in various forms from reproductions of traditional illustrations to contemporary manga and visual arts.

\section{Gray-zones and contradictions - pain, eating and normative femininity}

Suggesting the ideal, trendy women's clothes often come in just one size, and the thin-bodied woman is the most frequent female image shown in visual media, including the countless TV shows on food that (seemingly) involve eating large amounts of food and repeated ecstatic exclamation of oishii [delicious] and umai [tasty]. However, female participants in these shows usually cover their mouth with their hand, as if to reassure the audience of their controlled feminine appetite. This conveys a contradictive message that women can flirt with the image of the all-consuming female and passionately consume food, so long as they appear controlled and present themselves in a thin body.

Dieting and exercising to maintain a thin body requires tolerating pain and discomfort and involves two key motivational concepts: ganbaru [to make an effort] and gaman suru [to endure] (Spielvogel 2003: 23). These concepts are applied in the performance of contemporary normative femininity in specific ways beyond dieting and exercising. For example, a section headline in a 2007 women's magazine reads, "Hitomebore kutsu de aruite mitara ryūketsu!" [Trying to walk in the shoes you fell in love with at first sight - bloodshed!] (Baila, May 2007: 123), followed by advice on which shoes minimize pain and injury. Ironically most of the suggested "painless" shoes have toe-pinching forms and heels over 10 centimetres high. Likewise, rather than encouraging women to wear more comfortable shoes, one segment of the morning program Yajiuma terebi (aired by TV-Asahi on May 20, 2008) offered advice on how to cope with the pain from wearing fashionable shoes by performing special exercises with elastic bands.

Despite the pain and the possibility of permanent damage to ankles, toes and knees, stilettos and pointed shoes continue to be an essential part of a woman's wardrobe in Japan. Tolerating such pain requires a 
considerable amount of both ganbaru and garman suru, as thematized for instance in Yamada Eimi's short story "Jay-walk" (1990 [1989]: 131, 135), in which the high school protagonist complains that her feet hurt as she wears high heels for the first time. However, the only comfort given by her slightly older female acquaintance is that she must learn "not to feel the pain", meaning that in order to become feminine, women must be strong and accept pain. But whereas the Japanese expression tsuyoi otoko [strong man] is perceived as a positive attribute for a man, its counterpart tsuyoi onna [strong woman] has a negative connotation because it implies the woman is individualistic and selfish. To be feminine, then, women must live a contradiction: they must be strong to silently endure pain while appearing physically weak and inferior to men, who in turn are supposed to be physically strong.

Although normative practices, such as dieting, wearing high heels, wax hair removal and moderate plastic surgery, require individuals to restrict food intake and endure pain, they do not fall within the clinical definitions of self-harm and eating disorders, and we are usually not alarmed when we witness ordinary women engage in these everyday routines. Ear piercing is another practice that is not considered selfharm. But how about other forms of piercing, such as when Kanehara's protagonist in the novel Hebi ni piasu (2003: 95) forces a $2 \mathrm{~g}$ ring into her own tongue, causing blood to squirt out. Is this self-harm, or simply an act that allows the 19-year-old Rui to get a split tongue and be fashionable in her subculture? Since Kanehara's writings have often been connected to self-harm (Kume 2006; Otomo 2009), most readers would probably conclude that Rui's actions are indeed a type of selfharm. In Okazaki Kyōko's manga Herutā sukerutā (2003), where the protagonist undergoes a grotesque "feminization project" to transform into a fashion model, readers are also not in doubt - this is abnormal. However, why is it acceptable for women to injure themselves in other ways, whether dieting or wearing pointy-toed high heels? The many hammertoes, corns and bunions that adorn female toes revealed during the summer months certainly bring the phrase foot-mutilation to mind.

Such behavioural gray zones show how self-harm and eating disorders exist in a normatively accepted form in contemporary femininity: denying oneself food to a certain degree is considered positive and feminine and enduring pain to a certain degree is necessary to be fashionable and feminine. In addition, traditional Japanese feminine personality traits, like submissiveness and self-control as well as anticipating and satisfying the desire of others before one's own, are the same traits that are present, albeit in an extreme form, in many individuals with eating disorders (Ogura 2001: 8). In other words, the borderline between nor- 
mal and disorder is blurred and it is in these gray zones that contemporary women must navigate their femininity performance.

Recognizing that contemporary femininity shares common basic expressions with eating disorders and self-harm and that femininity is strongly rooted in the physical body (i.e., as birth giver and caretaker, beautiful and sexual object) provides clues why these self-violating behaviours are more prevalent among women than men. And, as the yamanba tales and Kaibara's writings show, the female competencies of restricting appetite and self-reproach were valued centuries before the early 1980's bodikon [body conscious] fashion. While this suggests how deeply rooted these expectations placed on women are in Japanese culture, it does not explain why eating disorders and self-harm suddenly increased from the 1980s onwards - a question of historical context that scholars on eating disorders have explored (Pike and Borovoy 2004).

In addition to the contradictory discourses on women, eating and pain, femininity as such has today become a difficult-to-navigate contradiction, leaving women feeling fragmented about what it means to be female. With the postwar constitution and the 1986 ratification of the Equal Employment Opportunity Law, women have been given the legal right, and the social obligation, to be subjects in the public sphere. ${ }^{5}$ However, existing biases in the education system and the prevalence of traditional patriarchal values in society have kept alive the expectation that girls will grow up to be caretakers and homemakers. The newly gained rights therefore continue to be contradicted through such discourses, in turn depriving women of their subjectivity (Katō 2004: 164-166). Thus, the traditional values and obligations placed on women have not been replaced, but have rather become extended. But although all Japanese women potentially face this contradiction, interviews show that women with eating disorders tend to feel particularly frustrated and fragmented by these mixed messages (Pike and Borovoy 2004: 494).

In cultural expressions, contradictive femininity and women's fragmentation are often depicted through opposing characters or encounters with alter egos and other selves. In Nakashima Tetsuya's film Shimotsuma monogatari (2004), which is based on Takemoto Nobara's (2002) novel of the same title, two different female characters, one delicate and cute and the other aggressive and tough are strangely drawn to each other. And, if we once again consider Miyazaki's animation, contradictive femininity is also expressed when Chihiro finds herself caught up in the sibling rivalry between the identical twins with opposing personalities - the tough business-oriented Yubāba, who runs a bathhouse, and the domestic Zeniiba, who knits and serves tea. 
However, unlike these fictional characters, real women cannot divide their own bodies into multiple separate beings. In order to perform contradictive femininity and cope with feelings of fragmentation, real women must develop strategies that allow them to navigate this paradox within the confines of their respective female bodies and realities.

\section{Individual experiences: Fragmented self and the war in the body}

All women in Japan potentially face the paradox of navigating contradictive femininity in a gray zone between the normal and the disordered, but only some women fail to navigate and engage in what are considered disordered practices. Such women have unique experiences with these acts, making a general understanding of their experiences with self-induced regurgitation, starvation or cutting impossible to construct. Instead, this paper offers one possible interpretation of women's experiences with eating disorders and self-harm. My interpretation is based on varied sources portraying both fictional and real women and is conceptualized by five socio-psychological markers (onset, feeling dirty, over-performance, alien invader and escape) that can be used to expose eating disorders and self-harm as embedded storylines in Japanese cultural expressions.

\subsection{Onset}

The onset (not the cause) of eating disorders or self-harm often occurs in tandem with social change, most commonly related to an emotionally charged event, such as the death of someone close, divorce or an emotionally violent encounter. However, social change is more often benign, such as receiving a negative comment from a close acquaintance or moving from one environment to another, like we see Chihiro and her parents do in the opening scenes of Sen to Chihiro no kamikakushi. In some cases, these experiences and the emotional pressure they create can evoke feelings of isolation and abandonment (Ogura 2001: 25-26; Saitō 1991; Yamamoto 2006: 152) and may result in the loss of "safe base". ${ }^{6}$ For example, in his 2001 book, neuropsychiatrist Kiriike Nobuo presents the case of a woman who began showing signs of eating disorders soon after she had left her job as a schoolteacher to become a full-time housewife. As her husband worked long hours, she was often alone in the house, and when her condition became severe she was hospitalized. Her husband never found the time to visit, and after repeatedly getting discharged and readmitted to hospital, her condition deteriorated and she began to cut herself (Kiriike 2001: 222). The change in her situation, from an outgoing supervising position to 
a passive wait-at-home wife, compounded by her husband's absence, led her to feel isolated and abandoned.

Feelings of abandonment triggering self-harm is depicted in the manga series Raifu, ${ }^{7}$ in which Ayumu starts to self-harm the same day her best friend Shii-chan angrily berates her upon discovering that only Ayumu was accepted to the high school they both aspired to enter (Suenobu 2002a: 51). What starts as a one-time experience escalates as Ayumu's friendship with Shii-chan breaks apart; soon after entering the new high school, Ayumu regularly cuts herself all over her body. In Katō Madoka's interviews with eating disordered women, escalation happens in a similar fashion. In one particular interview, subject $Y$ says that she began to restrict food shortly after entering middle school, and like Ayumu, her condition escalated when she had difficulties adjusting to her new surroundings (Katō 2004: 58). In both cases, the individual's feelings of isolation reinforce the goodness of past memories, which in Ayumu's case means she is unable to forget her friend's hurtful words, and instead of feeling unfairly treated she feels she only has herself to blame - she is the bad and selfish person.

All people experience dramatic changes and encounters at some point throughout their lifetime, but women engaging in eating disorders or self-harm tend to blame themselves to a high degree, as in Ayumu's case. Considering that self-reproach is one of the basic female competencies in Japan, advocated in Kaibara's Edo period writings, self-blame seems to be an obvious way to cope with feelings of isolation. In addition, if a child receives inconsistent responses to its desires during its upbringing from around the age of one and a half (when it becomes able to analyze psychologically) or encounters a traumatic experience (e.g., loss of safe base, surviving an accident), it may construct its own desires to be bad, and excuse the caretaker in order to re-establish some sense of safety (Ogura 2001: 17-18; Van der Kolk 1989). The child then creates an inner world based on self-punishment or self-suppression that, from around the age of six, can interact with the outer world, leading to negative effects often expressed through self-destructive behaviour (Van der Kolk 1989).

Returning to Miyazaki's animation, in a scene near the end of the story it becomes clear that Chihiro carries a past trauma because she suddenly recalls having fallen into a river during her early childhood. In the opening scenes it is also obvious that she is starved for the attention of her parents, who are exceptionally ignorant of her fear and sadness, and Chihiro's experience of her parents in pig-shape can therefore be interpreted as her attempt to excuse their lack of parental care. Her entire kamikakushi world experience can then be seen as an ex- 
pression of how she hides herself away in her own self-constructed inner world.

Like in the fictional cases of Chihiro and Ayumu, in real life the onset of eating disorders and self-harm often manifests as the child develops during its pre- or early-teenage years, although it can occur later in life (Ogura 2001: 17-18), as in the case of the former schoolteacher housewife from Kiriike's study.

\subsection{Feeling dirty}

Bulimics and self-cutters often express how they feel dirty. In Kanehara's novel Asshu beibī, club hostess Aya watches her blood seep out from a self-inflicted cut while wondering why it is so clean when she herself is so dirty (2004: 59). Being, or feeling, dirty is also a recurring expression in Kanaria no uta (Saitō 1991), a collection of letters sent to the Nippon Anorexia and Bulimia Association, ${ }^{8}$ where one woman describes how she stopped eating because she feared she would turn into a pig (Saitō 1991, vol. I: 6, 12). This pig-metaphor is also seen in pop-singer Cocco's 1998 song, "My dear pig", and is used on blogs by Japanese women with eating disorders to describe their own and other's food consumption. Based on this metaphor, it is possible to understand Chihiro's fear of becoming a pig and her experience of her parents in pig-shape as elements that further reinforce the embedded eating disorder storyline.

Just as food and eating are dangerous elements in Chihiro's world, food and feeling hungry are considered dirty, polluting and dangerous by both anorexics and bulimics, and the duality of being both obsessed with and afraid of appetite is almost always present in individuals engaging in eating disorders (Bordo 1993: 146). By rejecting food, anorexics feel clean and in control, and by throwing up, bulimics feel they regain control and become clean (Bordo 1993: 146, 148). Consequently, washing the body after having eaten or binged is common among women with eating disorders, highlighting the dichotomy of feeling "dirty" from eating and "clean" by purging. For example, after Saki, the model in Kanehara's novel Haidora (2007: 100-101), discards the obutsu [unclean] remains of food she has chewed and spat out, she cleans the kitchen and takes a bath to rid herself of any traces that might reveal her secret behaviour to her photographer boyfriend, who only photographs thin women.

In line with Saki's purification, Chihiro's self-constructed kamika$k u s h i$ world is a bathhouse - a place that, per definition, revolves around cleaning and purifying. From her determination to expel the river god Okusare-sama's filth to her subsequent scrubbing of the filthy 
bath, Chihiro becomes purified and socially integrated by expelling dirt and cleaning dirty things (Napier 2005: 184). And when she forces the bathhouse intruder Kaonashi to vomit by feeding it the remaining portion of Okusare-sama's emetic herbal cake, her act resembles how bulimics use emetic medicine as a purification tool to rid themselves of the consumed food and become clean.

Being clean and cleaning have deep roots in Japanese culture, represented not only by the cleansing rituals found in Buddhism and Shinto religion, but also by the widespread use and popularity of hot springs and bathhouses. Cleanliness likewise pervades daily activities through social routines such as the taking off of shoes before entering a room, the wiping of one's hands with wet towels before eating and the meticulous cleaning of the home and work place. Consequently, the feeling of being dirty and the fear of becoming dirty, combined with the culturally rooted storyline that women who express or satisfy their own desires are considered evil or bad, leads women to emphasize being clean and good by controlling their appetite. In this way, skinniness has come to symbolize cleanliness in contemporary Japan (Spielvogel 2003: 193).

\subsection{Over-performance}

When Ayumu, in Suenobu's manga series Raifu, thinks that she lost her best friend due to her own selfishness, her reasoning echoes the demands placed on females as espoused in the Edo-period writings of Kaibara Ekiken. She accordingly becomes self-reproachful (a positive quality according to Kaibara) and starts to punish herself by cutting her arms (probably not the method Kaibara had in mind) (Suenobu 2002: 47-85). Subject Y from Katō's interviews also believed her eating-disordered condition was self-induced and that she was a burden to her parents (Katō 2004: 54). Both Ayumu and Y internalize negative feelings and harshly punish themselves in order to become good. Ayumu plays the good friend to Manami, a girl from her new high school, in order to be accepted (Suenobu 2002a: 77-104), and Y neglects to sleep and studies harder in order to become a good daughter and compensate for letting her parents down (Katō 2004: 59). In both these cases, the fear of social disintegration seems to be an important motivator underpinning the effort to be good girls. But because Ayumu's and Y's actions are extreme, they can be considered an over-performance of femininity. Over-performance is typical in women who engage in eating disorders and self-harm, and it explains why young girls with eating disorders often act too adult, turning the parent-child relationship upside down (Kiriike 2001: 81, 83). From the moment Chihiro experiences her parents in pig-shape, the parent-child relationship is 
likewise reversed, and Chihiro assumes responsibility for the entire family's return to the normal world.

Being the good and clean girl implies suppressing the evil and allconsuming female. But because female-bodied individuals potentially inherit as evil nature through cultural images such as the ancient tales of the Yamamba, being good requires rejection of the female body and its desires and appetite, which explains why many women try to keep their behaviour a secret or else risk exposing their evil nature. This is why Saki in Haidora so carefully disposes the chewed food, cleans the kitchen and washes herself (Kanehara 2007: 100-101), and why Ayumu in Raifu vehemently denies that the scars on her arm are selfinflicted (Suenobu 2002b: 99). Women with eating disorders or who self-harm are aware that their actions are considered strange and disordered and they meticulously conceal their actions to avoid being found out (Bordo 1993: 148). The fear of social disintegration then reinforces feelings of isolation and strengthens the motivation to over-perform femininity.

The actions individuals undertake to over-perform depend on what "being good" means in each specific context. For Saki, whose relationship and career as a model depend on her being thin, being good means having a controlled appetite. In Chihiro's world, restricting food is also associated with being good and avoiding becoming a pig. However, in the case of Ayumu, being good means being submissive and free of selfishness. These characters' performances of their respective versions of being good require that they practice extreme self-reproach and selfcontrol within their specific contexts: avoiding consumption, spitting out food or cutting themselves. In this sense, eating disorders and selfharm can be considered desperate attempts by female individuals to literally carve their selves to fit into normative contradictive femininity - only in an extreme and fragmented form (McGilley 2004: 84).

\subsection{Alien invader}

Susan Bordo (1993) observes that women from western cultures with eating disorders tend to experience the body and mind as separated. Since psychologist Ogura Chikako (2001: 29) notes that Japanese women with eating disorders also experience this dualism, Bordo's findings (1993: 144-145, 155) are relevant: (i) the body is the not-self an alien - and inside the body is the real self; (ii) the body is a prison, swamp, cage or fog; (iii) the body is the enemy; and (iv) the body is the locus of all that threatens attempts to control: it overtakes, overwhelms, erupts and disrupts. Furthermore, many women describe this other self to be a ghost, a dominating dictator or a little man who is inside or 
surrounding them. Regardless of its form, this other self is almost always male, and is experienced through hunger, intruding as an alien invader from somewhere outside the self. Therefore, Bordo argues (1993: 146, 155), it becomes essential that the not-body - the self exercise power over the body in order to keep this invading character - the body - under control.

In Haidora, surprised by her own monstrous shape while noisily chomping ready-to-eat convenience store food and snacks, Saki describes herself as a machine (Kanehara 2007: 100). Likewise, after Fuku-chan in the Manga Daietto loses weight and becomes beautiful, she is pictured with devil teeth and wild hair during an eating binge (Ōshima 1995 [1989]: 116), depicting her transformation from her real self into an evil, uncontrollable creature with an insatiable appetite, just like the all-consuming yamanba.

The gendered nature of the relationship between the self and the other self, observed by Bordo, is touched upon in Raifu, when Ayumu's urge to cut her own body is personified by the appearance of a disembodied male acquaintance (Suenobu 2002b: 115). This issue also appears in one scene in Ogawa Yōko's novel Shugā taimu (2006 [1991]: 143-150), which revolves around university student Kaoru, a part-time restaurant worker, and her concerns about her appetite. One day, while Kaoru is tending the restaurant on her own a short man enters and orders the special of the month. When he first appears, he is referred to as "that man", underscoring his significance to the reader. Shortly thereafter, the other patrons vanish, leaving Kaoru and the short man alone as she prepares his meal. She intensely watches him eat, noticing how he does not leave a single breadcrumb behind. The entire scene then takes on a strange atmosphere, and it is unclear if the man is real or a figment of Kaoru's imagination. However, at one point, when the short man asks for more water, he phrases his request using kashira, a sentence-final particle mainly used by women. This suggests that Kaoru has constructed the short man in her mind using her own female language, making him a projection of her own other self.

Like Bordo, sociologist Asano Chie (1998 [1996]) also observes that the dual self tends to be gendered in its fragmentation, but in contrast to Bordo's findings, where the other self usually takes a male form, Asano depicts the division as between female-like and self-like. These two are expressed as separate entities by Asano's interviewees, often described through contradictions, such as "I want to stay a cute little girl" in tandem with "I want to become a leader" (Asano 1998 [1996]: 13). However, regardless of which gender the two selves take, it is clear that their war-like conflict revolves around gender. It is this war that anorexics refuse to lose when they express fear of taking even one bite 
(Bordo 1993: 146, 155), and it is this war that bulimics (momentarily) win every time they throw up. A similar war occurs when women intentionally harm themselves to fulfil the desire of (momentarily) breaking free from the bodily prison.

This inner war is depicted in Raifu by the image of a faceless female character running out and away as the blood drips from Ayumu's selfinflicted wound (Suenobu 2002a: 153-154), and in Asshu beibī by Aya's self-abusive conversation between her two selves, one weak and one in control (Kanehara 2004: 57-62). Chihiro's confrontation with the bathhouse intruder Kaonashi can likewise be understood as a war against appetite and desire that she heroically wins by making Kaonashi regurgitate the massive amounts of food it has consumed. Upon her successful diminishing of Kaonashi to its former voiceless, harmless and slim shape, Chihiro's heroic actions restore harmony throughout the bathhouse and she is cheered (i.e., socially integrated) by everyone.

When considering the soothing feelings of "relaxation and safety" that the pain from the knife provides self-harmers (Yamamoto 2006: 151), and the "peace and purity" experienced by bulimics after their self-induced regurgitation, eating disorders and self-harm paradoxically become a form of self-help (McGilley 2004: 77-78), a temporary truce between the self and the alien invader on the bodily battlefield.

\subsection{Escape}

Compared to Miyazaki's other shojo protagonists such as Satsuki in Tonari no totoro (1988) or Kiki in Majo no takyübin (1989), Chihiro is unusually skinny. However, Chihiro's food refusal is not based on an explicit desire for thinness - she just senses that eating the displayed food is dangerous. Similarly, a conscious desire to be thin is not the universal motivator driving Japanese women towards eating disorders (Pike and Borovoy 2004: 513).

In Katō's (2004: 47-49) interviews, subject Y recalls that she did not have a particular desire to lose weight or become beautiful - she just lost her appetite. Her fears were more connected to the changes taking place in her body, especially those related to becoming an adult woman. Being a girl, she thought, meant that she was destined to become a housewife like her mother, and although she was grateful to her mother for giving up career opportunities to take care of the home, she also felt that her mother had been "locked up" in the family. Y's experiences as a female and with femininity thus involves sacrifice i.e., giving up life in the public domain - and submission - i.e., being trapped like a prisoner in the private domain. Because she both admires and opposes these obligations, she holds on to a contradictory 
set of values, and the war in her body - anorexia - reflects her fragmentation between these two opposing roles.

Japanese women with eating disorders, such as subject Y, have a significantly greater fear of maturity than their North American counterparts (Pike and Mizushima 2005: 28). This observation suggests that their attempts to shrink or harm their bodies by not eating or by cutting themselves are symbolic ways of escaping the responsibilities attached to the female body. By insisting on being thin, Japanese women reject traditional gender roles (Miller 2006: 174; Spielvogel 2003: 198), and trapped women, from the former schoolteacher housewife in Kiriike's study to subject $\mathrm{Y}$, somehow remind us of hunger striking prisoners conveying a political message, which Japanese anorexics have been compared to (see Spielvogel 2003: 193). The key difference, however, is that unlike political prisoners, these women are often unclear about the message they want to convey and what it is they are protesting against. As many scholars have pointed out, individuals engaged in eating disorders or self-harm usually do not experience their own situation as a political act (Asano 1998 [1996]: 24-25; Björk 2000: 202; Bordo 1993: 144, 159). But by controlling food intake like the heroic Chihiro in her self-constructed kamikakushi world, Y expresses an attempt to both avoid being an all-consuming female and escape the destiny she feels she is expected to live out as a woman. The former schoolteacher housewife in Kiriike's study likewise desperately starves and cuts her way out of the domestic prison where she is confined due to her social standing as a married woman. The irony here is that by becoming thinner, smaller and turning into victims, these women move closer to the very core of what femininity is constructed to be in contemporary Japan.

\section{Conclusion: Lifestyle and entertainment}

Eating disorders and self-harm have been on the rise since the 1980s. These behaviours are deeply tied to both historical and contemporary constructions of femininity in Japan. Self-reproach and a controlled appetite are valued female characteristics in ancient folk tales and past philosophical writings, and because contemporary femininity, which consists of opposing values, shares elements with eating disorders and self-harm behaviour, women today perform a contradictive femininity in a gray zone between normative (i.e., wearing high heels, piercing and dieting) and disorder (i.e., cutting, anorexia and bulimia).

This difficult-to-navigate femininity provokes feelings of fragmentation and frustration over how to be female, and eating disorders and self-harm behaviour express a paradox - an attempt to both over- 
perform and escape the obligations of contradictive femininity. But regardless of whether women are performing femininity within normative boundaries or are diagnosed with a clinical disorder, tolerating pain and depriving the body are an inseparable part of contemporary women's daily routines. Therefore, eating disorders and self-harm should not only be considered disordered acts but also be understood as a contemporary female lifestyle.

As with most lifestyles in contemporary Japan, this particular female lifestyle is also a form of entertainment. Since the 1980s, eating disorders and self-harm have not only been explicitly thematized in various cultural expressions, from literature to manga and anime, but are also present via embedded storylines in works where these behaviours are not explicitly thematized. The five socio-psychological markers developed in this paper - onset, feeling dirty, over-performance, alien invader and escape - expose how Chihiro's agency in Miyazaki Hayao's animation is based on key elements related to eating disorders: refusing to consume and expelling the consumed. And because Chihiro is not a victim but a hero, who is cheered by her fellow characters and celebrated by her audience, Miyazaki's animation seems to suggest that eating disorders are now a lifestyle that allows women to position themselves as heroes. Similar embedded storylines potentially exist in other contemporary cultural expressions. For example, in Murakami Haruki's short story "Midori iro no kemono" (1991), a lonely housewife protagonist cuts, stabs and burns a green monster that can be understood to represent her own other self (Hansen: 2011, forthcoming). Applying the marker of alien invader to Murakami's housewife protagonist would then expose her actions to be self-harm, similar to how Chihiro's heroic acts can be exposed as anorexic and bulimic behaviour.

The five socio-psychological markers are not meant to be a finalized set of analytical tools; my hope is that they can function as stepping stones to expand analytical approaches and research on eating disorders and self-harm as a lifestyle that is performed and consumed in Japanese culture. As pop-singer Cocco exemplifies, consumption of this lifestyle only seems to become trendier - her front-cover appearance in the November 2009 issue of culture magazine Papyrus promotes her cadaverously thin body, decked out in a cute and trendy ballerinastyle dress, arms and chest marred with bruises and cuts. But despite this trendy image, published near the end of the first decade of the 21st century, the lyrics from "Way Out" on her 1997 album, "Doredake chi o haitemo, kotae nante doko nimo nakatta" [No matter how much blood I threw up, the answer was nowhere], are still highly relevant: 
neither throwing up nor cutting one's own skin are good enough answers to the question on how to be female.

Gitte Marianne Hansen (gitte.marianne.hansen@gmail.com) is a Ph.D. candidate and Gates Cambridge Trust scholar in Japanese studies at the University of Cambridge, and a visiting researcher at the Organization for Asian Studies, Waseda University. She holds an M.A. from the University of Copenhagen, and from 2004 to 2009 she studied and worked as a teaching and research assistant at Waseda University. Her research looks at contemporary Japanese cultural expressions and women as agents of violence unto themselves and towards others. She is also working on Murakami Haruki's "female narrative works", part of which is published in Japan Studies Association Journal (2011).

\section{Notes}

1. Storylines are condensed versions of cultural narratives used as explanatory frameworks to justify individuals' practice and sequence of actions (Søndergaard 2002: 191). Accordingly, embedded storylines are cultural narratives that exist beneath the main plot.

2. Although eating disorders and self-harm are more prevalent among women, men also engage in these practices. The current expression sōshoku-kei danshi [planteating men], in addition to the increasing male-body conscious fashion, suggests that these behaviours are likely to be on the increase among men. However, given the lack of comprehensive data to confirm such an upwards trend, this study focuses on women.

3. Gender is a social construction, performed by members of a social context (Butler 1990). Failure to perform within the norm can result in social disintegration, motivating individuals to adhere to socially accepted norms of femininity and masculinity (Søndergaard 1996: 20, 33-34; 2002: 198).

4. Personal communication with M. D. Ihara Kazushige on March 27, 2010.

5. The equal employment opportunity law was modified in 2006 to address equality shortcomings (Starich 2007).

6. The concept of "safe base", developed in the field of attachment theory, describes how individuals need a place (e.g., friends, family) where they can find support and security in order to be psychologically healthy. Loss of safe base is similar to a traumatic experience and can affect social development, often resulting in selfdestructive behaviour among females and outwardly destructive behaviour among males (Van der Kolk 1989).

7. In June 2007, Fuji TV dramatized Raifu as a television series. However, scenes involving self-harm were omitted.

8. The Nippon Anorexia Bulimia Association was established in 1987 with the aim of providing assistance to individuals with eating disorders.

\section{References}

Anno, Moyoko. 1997. Shibō to iu na no fuku o kite [Dressed in the clothes named fat]. Tokyo: Shufu to Seikatsusha. 
Asano, Chie. 1998 [1996]. Onna wa naze yaseyō to suru no ka [Why do women want to lose weight?]. Tokyo: Keisō Shobō.

Baila. May 2007. Ashigata betsu - hontō ni itaku naranai oshare kutsu [Shoe special - trendy shoes that really don't hurt]. 123-129.

Barthes, Roland. 1976 [1972]. Mythologies. London: Paladin.

Björk, Nina. 2000. Sirenernes sang [Song of the sirens]. Copenhagen, Denmark: Tiderne Skifter.

Bordo, Susan. 1993. Unbearable weight - feminism, western culture and the body. Los Angeles, CA: University of California Press.

Butler, Judith. 1999 [1990]. Gender trouble: Feminism and the subversion of identity. New York: Routledge.

Coeyman, Marjorie. 2002. A Japanese animator with a timeless style. http://www. csmonitor.com/2002/0809/p20s01-alip.html (last accessed 5 October 2010).

Foucault, Michael. 1972. The archaeology of knowledge. London: Tavistock.

Hall, Stuart (ed.). 1997. Representation: Cultural representation and signifying practices. London: Sage.

Hansen, Gitte Marianne. 2011, forthcoming. Murakami Haruki's female narratives: Ignored works show awareness of women's issues. Japan Studies Association Journal 8.

Hosogai, Sayaka. 2003. Dai-27-kai Subaru bungaku-shō "Kanehara Hitomi" [27th Subaru prize for literature, "Kanehara Hitomi"]. Subaru Bungaku Kafe [Subaru literary café] 11. http://subaru.shueisha.co.jp/html/person/p0311k_f.html (last accessed 5 October 2010).

Iijima, Yoshiharu. 1987. Folk culture and the liminality of children. Current Anthropology 28 (4). $41-48$.

Kaibara, Ekiken. 1911 [1762]. Onna daigaku [Greater learning for women]. In $E k$ iken zenshū, III, 686-691. Tokyo: Ekiken Zenshū Kankōbu.

Kanehara, Hitomi. 2004 [2003]. Hebi ni piasu [Snakes and earrings]. Tokyo: Shūeisha.

Kanehara, Hitomi. 2004. Asshu beibī [Ash baby]. Tokyo: Shūeisha.

Kanehara, Hitomi. 2007. Haidora [Hydra]. Shinchō 104 (1). 88-141.

Katō, Madoka. 2004. Kyoshoku to kashoku no shakaigaku [Sociological study of anorexia and bulimia]. Tokyo: Iwanami Shoten.

Kawai, Hayao. 1982. Mukashibanashi to Nihonjin no kokoro [The Japanese psyche: Major motifs in the fairy tales of Japan]. Tokyo: Iwanami Shoten.

Kinsella, Sharon. 2005. Black faces, witches, and racism against girls. In Laura Miller \& Jan Bardsley (eds.), Bad girls of Japan, 127-141. New York: Palgrave Macmillan.

Kiriike, Nobuo. 2001. Minna de manabu kashoku to kyoshoku to daietto [Together we learn about anorexia, bulimia and dieting]. Tokyo: Seiwa Shoten.

Kume, Yoriko. 2006. Itami he no kikyū. Hebi ni piasu - Kanehara Hitomi [Longing for pain. Snakes and earrings - Kanehara Hitomi]. In Iwabuchi Hiroko \& Hasegawa Kei (eds.), Jendā de yomu ai, sei, kazoku [Reading through gender: Love, sex, family], 100-110. Tokyo: Tokyodō Shuppan.

Lee, Sing. 2001. Fat phobia in anorexia nervosa: Whose obsession is it? In Mervat Nasser, Melanie A. Katzman \& Richard A. Gordon (eds.), Eating disorders and cultures in transition, 40-64. East Sussex, England: Brunner-Routledge.

Makino, M., M. Hashizume, M. Yasushi, K. Tsuboi \& L. Dennerstein. 2006. Factors associated with abnormal eating attitudes among female college students in Japan. Archives of Women's Mental Health 9 (4). 203-208.

Matsumoto, Yūko. 1987. Kyoshokushō no akenai yoake [Anorexia, dawn that never breaks]. Tokyo: Shūeisha. 
McGilley, Berth H. 2004. Feminist perspectives on self-harm behaviour and eating disorders. In John L. Levitt, Randy A. Sansone \& Leigh Cohn (eds.), Self-harm behavior and eating disorders. Dynamics, assessment, and treatment, 75-89. New York: Brunner-Routledge.

Miller, Laura. 2006. Beauty up: Exploring contemporary Japanese body aesthetics. Los Angeles: University of California Press.

Miyazaki, Hayao (director). 1988. Tonari no Totoro [My neighbour Totoro]. Tokyo: Sutajio Jiburi.

Miyazaki, Hayao (director). 1989. Majo no takyūbin [Kiki's delivery service]. Tokyo: Sutajio Jiburi.

Miyazaki, Hayao (director). 2001. Sen to Chihiro no kamikakushi [Spirited away]. Tokyo: Sutajio Jiburi.

Murakami, Haruki. 1991. Midori iro no kemono [The little green monster]. Murakami Haruki bukku [Murakami Haruki book]. Bungakukai 4. 30-34.

Nakamura, Kazutoshi, Hoshino Yoshihiko, Watanabe Atsushi, Honda Kyoichi, Niwa Shinichi \& Yamamoto Masaharu. 1999. Eating problems and related weight control behaviour in adult Japanese women. Psychotherapy and Psychosomatics 68 (I). 51-55.

Nakashima, Tetsuya (director). 2004. Shimotsuma monogatari [Kamikaze girls]. Tokyo: Studio $4^{\circ} \mathrm{C}$.

Napier, Susan J. 2005. Anime from Akira to Howl's moving castle. New York: Palgrave Macmillan.

Ogawa, Yōko. 2006 [1991]. Shugā taimu [Sugar time]. Tokyo: Chūōkōron-shinsha.

Ogura, Chikako. 2001. Sekushuariti no shinrigaku [Psychological study of sexuality]. Tokyo: Yūhikaku.

Okazaki, Kyōko. 2003. Herutā sukerutā [Helter skelter]. Tokyo: Shōdensha.

Ōshima, Yumiko. 1995 [1989]. Daietto [Diet]. Ōshima Yumiko senshū 1. 73-136. Tokyo: Mainichi Sonorama.

Otomo, Rio. 2009. A girl with her writing machine: Amoebic by Kanehara Hitomi. In Tomoko Aoyama \& Barbara Hartley (eds.), Girl reading girl in Japan, 130141. London: Routledge.

Pike, Kathleen M. \& Amy Borovoy. 2004. The rise of eating disorders in Japan: Issues of culture and limitations of the model of "westernization". Culture, Medicine and Psychiatry 28 (4). 493-531.

Pike, Kathleen M. \& Hiroko Mizushima. 2005. The clinical presentation of Japanese women with anorexia nervosa and bulimia nervosa: A study of the eating disorders inventory-2. International Journal of Eating Disorders 37. 26-31.

Saitō, Satoru (ed.). 1991. Kanaria no uta [The canary bird's song], vol. I-II. Tokyo: Dōbutsusha.

Spielvogel, Laura. 2003. Working out in Japan: Shaping the female body in Tokyo fitness clubs. Durham, NC: Duke University Press.

Starich, Megan L. 2007. The 2006 revisions to Japan's Equal Opportunity Employment Law: A narrow approach to a pervasive problem. Pacific Rim Law \& Policy Journal 16. 551-578.

Suenobu, Keiko. 2002a. Raifu [Life], vol. I. Tokyo: Kōdansha.

Suenobu, Keiko. 2002b. Raifu [Life], vol. II. Tokyo: Kōdansha.

Søndergaard, Dorthe Marie. 1996. Tegnet på kroppe: Køn koder og konstruktioner blandt unge voksne $i$ academia [The sign on the body: Gender, codes and construction among young adults in academia]. Copenhagen: Museum Tsuculanums Forlag.

Søndergaard, Dorthe Marie. 2002. Postructuralist approaches to empirical analysis. International Journal of Qualitative Studies in Education 15 (2). 187-204. 
Takemoto, Nobara. 2002. Shimotsuma monogatari [Shimotsuma story]. Tokyo: Shōgakukan.

Van der Kolk, Bessel A. 1989. The compulsion to repeat the trauma: Re-enactment, revictimization, and masochism. Psychiatric Clinics of North America 12 (2). 389-411. http://www.cirp.org/library/psych/vanderkolk/ (last accessed 5 October 2010).

Yamada, Eimi. 1990 [1989]. Jay-walk. In Hōkago no kiinōto [After-school keynotes]. 115-136. Tokyo: Shinchōsha.

Yamaguchi, Motoko. 2009. Yamanba, yama o oriru. Gendai ni sumau mukashi-banashi [Mountain crone comes down the mountain. Ancient tales inhabit the present]. Tokyo: Shinyōsha.

Yamaguchi, Akiko \& Matsumoto Toshihiko. 2005. Joshi kōkōsei ni okeru jishōkōi [Self-harm behaviour in high-school girls]. Seishin Igaku [Mental health medical studies] 47 (5). 515-522.

Yamamoto, Noriko. 2006. "Kietai" shōkōgun ["Wanting to disappear" syndrome]. Tokyo: Kyōiku Shiryō Shuppankai.

Yanagita, Kunio. 1976 [1910]. Tōno monogatari [The legends of Tono]. Tokyo: Iwanami Shoten.

Yanagita, Kunio. 1976 [1926]. Yama no jinsei [Mountain life]. Tokyo: Iwanami Shoten. 